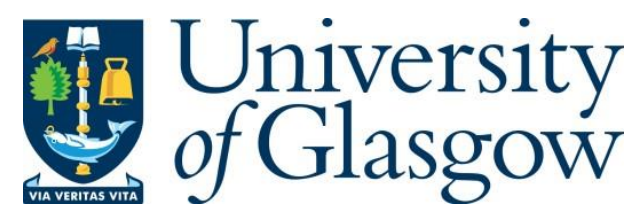

Azer, J. and Alexander, M. (2020) Direct and indirect negatively valenced engagement behavior. Journal of Services Marketing, 34(7), pp. 967-981.

There may be differences between this version and the published version. You are advised to consult the publisher's version if you wish to cite from it.

http://eprints.gla.ac.uk/212553/

Deposited on: 20 March 2020

Enlighten - Research publications by members of the University of Glasgow http://eprints.gla.ac.uk 


\title{
Direct and Indirect Negatively Valenced Engagement Behavior
}

\author{
Jaylan Azer \\ Department of Management, Adam Smith Business School, University of Glasgow, \\ Glasgow, UK \\ $\&$ \\ Matthew Alexander \\ Department of Marketing, Strathclyde Business School, University of Strathclyde, \\ Glasgow, UK
}

\begin{abstract}
Purpose - This study shows the impact of direct and indirect customers' negatively valenced influencing behavior (NVIB) on other actors in online social networks.

Design/methodology/approach - Four experiments were conducted in an online review setting that encompasses both restaurant and hotel reviews. The first study compares the impact of direct and indirect NVIB. The second, third and fourth studies measure this impact moderated by aggregate ratings, the volume of positive reviews and managerial responses. Findings - Drawing on recent literature of customer engagement behavior (CEB), online reviews and social influence theory (SIT), this paper provides the first empirical results of the impact of direct and indirect NVIB, revealing the significant difference in their impact and the moderating role of the aggregate ratings, number of positive reviews and managerial responses on the cause-effect relationship between direct and indirect NVIB and other actors' attitudes and behavioral intentions towards service providers.
\end{abstract}

Research limitations - TripAdvisor reviews were selected for the reason of appropriateness rather than representativeness, using two service providers, hotels and restaurants.

Practical implications -This paper provides managers with new insights, which capture not only what customers say about service providers but also the impact of how they say it, suggesting that managers move beyond framing NVIB in generalized terms to considering the differences in the impact of its direct and indirect facets.

Originality/value - This research is the first to provide empirical results about the significant difference in the impact of direct and indirect NVIB on other actors' attitudes and behavioral intentions toward service providers, moderated by different heuristics, namely ratings, volume of positive reviews and managerial responses.

Keywords - Customer engagement behavior, e-WOM, experiments, influencing behavior, managerial response, online reviews, ratings, social networks, TripAdvisor, volume of reviews

Paper type - Research paper 


\section{Introduction}

In the digital age, customers' positive or negative social influence on other actors in online networks is becoming increasingly significant in service research (Alexander et al., 2018, Brodie et al., 2019). Recent research on customer engagement behavior (CEB) formalizes this influence as influencing behavior, which refers to customers' contribution of knowledge, experience and time to affecting other actors' expectations, perceptions and knowledge about service providers (Jaakkola and Alexander, 2014). Influencing behavior as a form of CEB is frequently manifested in online user-generated content, with the potential to impact how other actors evaluate the value of offerings; consequently, attitudes and behaviors towards service providers can also be affected, ultimately affecting a firm's value based on its valence (Azer and Alexander, 2018, Lemon and Verhoef, 2016). The valence of influencing behavior reflects the extent to which particular service outcomes are perceived by customers as good or bad and is considered challenging for being uncontrollable in most instances (Brady et al., 2006). Additionally, its importance lies in its potential impacts: positively (negatively) valenced influencing behavior might have favorable (detrimental) long-term financial, relational and reputational consequences on services, products, brands, or firms (Keiningham et al., 2018, Kumar et al., 2010, Van Doorn et al., 2010).

Although firms are increasingly devoting their strategic efforts to fostering positively valenced influencing behavior for their organizations (Harmeling et al., 2017, Lemon and Verhoef, 2016), the challenge for service providers to develop appropriate strategies to manage negatively valenced influencing behavior (NVIB) centers on understanding the heterogeneity of its forms and, hence, its different negative impacts (Dolan et al., 2019, Juric et al., 2016). In particular, recent research on online reviews reveals that customers' NVIB is not homogenous but that they either advise other actors in their reviews what not to do (direct) or just share their negative experience without giving explicit advice (indirect) (Azer and Alexander, 2018). Although prior research has shown that customers are influenced by the choices and opinions of other customers on products and services (Blasco-Arcas et al., 2014, Kumar et al., 2010), it captures customers' influential roles only in terms of recommending or warning others (Blazevic et al., 2013, Jaakkola and Alexander, 2014, Verhoef et al., 2010). However, these roles typically involve explicitly advising others and thus far, no studies have investigated the impact of indirect NVIB and how its impact may differ from direct NVIB (Azer and Alexander, 2018). Most existing research ignores the 
heterogeneity of negatively valenced reviews (Balaji et al., 2016) although, it would be more valuable to capture the impact of not only what customers say about service providers but how they say it (Hennig-Thurau et al., 2010). Central to social influence theory (SIT), even minimal differences in the way customers exert influence via direct and indirect NVIB can have a significant effect on other actors' evaluations (Cohen and Golden, 1972). This aspect is new and has been overlooked in the extant literature, which assumes an aggregate negative impact of negative reviews (Balaji et al., 2016, Hennig-Thurau et al., 2010). This has caused a major limitation in e-WOM research stream with inconclusive findings regarding the impact of negative valence compared to ratings and volume of juxtaposed positive reviews (Cheung and Thadani, 2012, Hennig-Thurau et al., 2010, King et al., 2014).

Accordingly, despite NVIB's potentially detrimental effects, an understanding of it remains scant in literature (Osuna Ramírez et al., 2019, Veloutsou and Mafe, 2020) especially empirically, and specifically regarding the impact of its direct and indirect facets (Azer and Alexander, 2018, Hollebeek et al., 2016). Practically, this is important to service providers as the specific performances required to foster a firm's value or avoid value destruction can differ based on the relative strength of the impact of direct and indirect NVIB (Azer and Alexander, 2020, Dolan et al., 2019).

This paper draws from CEB, online reviews literature streams and SIT to provide empirical insights into this important yet under-researched area. Thus, this study fills this research gap by providing the first empirical study measuring the impact of direct and indirect NVIB on other actors' attitudinal and behavioral outcomes using four betweensubject experimental studies. Study 1 measures the impact of direct compared to indirect NVIB. Studies 2, 3 and 4 measure their impact moderated by aggregate ratings, volumes of positive reviews and managerial responses, respectively. Therefore, this paper contributes to the growing literature on online reviews, which has predominantly concentrated on the impact of what customers say about service providers in their online reviews rather than the impact of how they say it, and provides the first empirical results about the significant difference in the impact of direct and indirect NVIB, moderated by different heuristics, namely ratings, volume of positive reviews and managerial responses. Additionally, this paper advances research on $\mathrm{CEB}$, especially the impact of its negative valence on other actors in social networks, which has so far been nebulous (Bowden et al., 2017). Practically, this paper offers service providers and third-party retailers (e.g. Amazon, Booking.com, 
TripAdvisor) with a clearer way of understanding the heterogeneity of direct and indirect NVIB and the variation of their impact on other actors. Using the findings of this study, managers will be able to develop mitigating and response strategies.

\section{Literature Review and Hypotheses}

\section{Social Influence Theory (SIT) and Customer Engagement Behavior (CEB)}

Since customers are exposed to social influence via online reviews when evaluating services and products, SIT is an appropriate theory and was adopted to offer insights into this research. SIT advocates that customers are influenced by the choices and opinions of other customers about products and services (Book et al., 2016, Gavilan et al., 2018); hence, social influence is one of the important factors in customers' evaluations and decision-making processes (Book et al., 2016, Burnkrant and Cousineau, 1975). Importantly, central to this research is that SIT suggests that even minimal differences in the way customers exert influence can have a significant effect on other actors' evaluations (Cohen and Golden, 1972).

Understanding CEB has become one of the top priorities for firms and an important research perspective in marketing and business (Lemon and Verhoef, 2016, MSI, 2016, Van Doorn et al., 2010) as it has the potential to affect the value and performance of firms (Kunz et al., 2017). CEB refers to customers' beyond the transactional behavioral manifestations (Van Doorn et al., 2010). Negative or positive CEBs reflect how customers perceive specific service outcomes as good or bad (Brady et al., 2006, Högström et al., 2010). Specifically, negative CEBs might have detrimental financial and relational consequences on firms (Kumar et al., 2010, Kunz et al., 2017, Van Doorn et al., 2010). However, despite its potential impacts and relationship to key outcomes for customer-brand relationship such as loyalty, lifetime and shareholder value (Verleye et al., 2014), the majority of studies address positively valenced CEB, thus, largely overlooking the negative side and its ensuing implications (Hollebeek et al., 2016, Osuna Ramírez et al., 2019). Specifically within online contexts, negative CEBs are contagious and viral in nature, with ensuing implications that may involve potential short and long-term financial and reputational detrimental outcomes for firms, brands and service providers (Bowden et al., 2017, Wu et al., 2016). 
Recent research focusing on CEB within service ecosystems has identified influencing behavior as a form of CEB that relates to customers' contributions of their knowledge, skills, time and experience to impact other actors' knowledge, perceptions and expectations about focal service providers (Jaakkola and Alexander, 2014). Influencing behavior is manifested in a range of communication tools, such as WOM, e-WOM (e.g. online reviews), referrals, recommendations, blogging and mobile apps, which are utilized to spread influence (Azer and Alexander, 2018, Jaakkola and Alexander, 2014, Kumar et al., 2010). NVIB refers to customer contributions of their knowledge, skills, experience and time to negatively affect other actors' knowledge, expectations and perceptions about service providers (Azer and Alexander, 2018).

Previous research has examined customers' influence via online reviews (the focus of this paper) on trip planning (Ayeh et al., 2013, Berezina et al., 2015) and on hotel performance (Phillips et al., 2017, Ye et al., 2009). Other studies have considered the heterogeneity of negative online reviews (Azer and Alexander, 2018, Dolan et al., 2019), the importance of hotels' responses to online reviews (Sparks et al., 2016, Wei et al., 2013), the effects of review valence (Filieri and McLeay, 2014, Lee et al., 2017) and source credibility (Choi et al., 2016, Zhang et al., 2016). Despite interest in the impact of negative reviews, empirical results from previous studies offer mixed findings even when studies focus on the same empirical context (Babić Rosario et al., 2016). For instance, negative reviews negatively impact attitudes towards products or brands (Lee et al., 2009); however, other studies suggest that this impact occurs only when customers are exposed to a specific volume of negative reviews (Lee et al., 2008) for lesser-known brands (Vermeulen and Seegers, 2009) or utilitarian products (Sen and Lerman, 2007). In terms of purchase intentions, there are conflicting findings on whether they have a negative impact on customers' purchase intentions (Qiu et al., 2012, Sen and Lerman, 2007, Zhang et al., 2010) while other authors have found a counterintuitive effect of negative reviews in enhancing the behavioral intentions of customers who feel a close connection toward the brand (Wilson et al., 2017). Importantly, thus far, the analysis of most of the extant studies assumes an aggregate impact of negative reviews (Hennig-Thurau et al., 2010, King et al., 2014) despite suggestions that the negative impact may differ as some reviews may have a stronger negative impact than others (Azer and Alexander, 2018, King et al., 2014). 


\section{Direct and Indirect Negatively valenced Influencing Behavior}

The extant e-WOM literature shows that customers are influenced by the choices and opinions of other customers on products and services (Azer, 2015, Blasco-Arcas et al., 2014), capturing customers' influential roles only in terms of recommending, referring or warning others (Blazevic et al., 2013, Jaakkola and Alexander, 2014, Verhoef et al., 2010).

Noticeably, these roles typically involve explicit advice to others on what to or not to do, but, when customers are just sharing their experience without explicitly advising others in their reviews, whether that would show any difference in the negative impact of their reviews is, as yet, unknown.

Recent studies have shown that NVIB within online reviews is not homogenous and can be classified into direct and indirect categories. Direct NVIB incorporates an explicit advice to other customers not to transact with a specific provider and stressing opposition to providers based on an unfavorable experience, whereas indirect NVIB makes general comments about service providers without any explicit advice to other actors not to transact with this provider (Azer and Alexander, 2018). To illustrate, both direct and indirect NVIB encompass details of substandard service in a functional way that incorporates the evaluation of the service environment, quality and staff; however, with direct NVIB, customers tend to explicitly advise other actors not to transact with focal service providers using exhortations such as 'Don't go there' while with indirect NVIB, they do not (Azer and Alexander, 2017). Similarly, within parallel research stream on complaining behavior, Dolan et al. (2019) show that complaining is not the same for all customers; it could involve informing or advising other customers. Consistently, other views suggest that WOM/e-WOM messages can be descriptive and injunctive in nature (Lee et al., 2008, Schultz et al., 2008).

Social psychologists describe customers exerting influence as influencing agents and claim their intentions are to adjust how others feel, think and behave towards a specific cause or object (Zimbardo and Leippe, 1991). Individuals' thoughts (cognition) and feelings (affect) form their attitudes towards a focal object (Fishbein and Ajzen, 1975), and attitude might affect behavior at a later stage (Maio et al., 2018). Therefore, NVIB potentially has a negative effect on other actors' attitudes and behavioral intentions (Bowden et al., 2017, Schaefers and Schamari, 2016, Wünderlich et al., 2013). However, how this negative impact varies with direct or indirect NVIB has not yet been explored, although it would be more valuable to capture the impact of how customers exert influence via direct and indirect NVIB 
(Azer and Alexander, 2018, Hennig-Thurau et al., 2010), which has been overlooked in the literature although assessments of this negative impact may differ (Dolan et al., 2019, King et al., 2014).

According to prior research, when exposed to negative reviews, customers tend to attribute the negative experience to the incapacity of the service provider (Folkes and Kotsos, 1986, Jiang et al., 2010, Qiu et al., 2012). The influence of negative customer reviews, according to SIT, relates to the acceptance of advice from others (Burnkrant and Cousineau, 1975). Moreover, SIT suggests that even minimal difference in the way customers exert influence can have a significant effect on other actors' evaluations (Cohen and Golden, 1972); accordingly, the way customers exert influence via NVIB by explicitly advising other actors or not, may have a significant difference on their attitudes and behaviors towards service providers. Based on prior research on descriptive and injunctive messages (cf. Schultz et al., 2008), indirect NVIB is to a great extent descriptive in nature while direct NVIB is more injunctive (Azer and Alexander, 2018). The extant empirical research shows that injunctive messages are more persuasive than descriptive ones (Lee et al., 2008, Schultz et al., 2008). Accordingly, to measure the impact of direct versus indirect forms of NVIB, we hypothesize that:

H1: Direct NVIB will have a stronger negative impact than indirect NVIB on other actors' (i) attitudes and (ii) behavioral intentions towards service providers.

\section{Study 1: Direct vs. Indirect NVIB}

\section{Design and Procedures}

This experiment tests $\mathrm{H} 1$ using a two independent groups design. Following the recommendation by Hair et al. (2010), for an adequate sample size to achieve at least 0.05 of the alpha level with an acceptable power level of 0.8 (Cohen, 1988), a sample of 100 university students (females $65 \%$, average age $=21.31$ years, $S D=1.29$ ) was compiled. Sampling university students have been accepted in service research for access and validity purposes (e.g. Albrecht et al., 2016, Smith and Bolton, 1998). Data was collected using the Qualtrics online survey facility. We made up the scenarios like TripAdvisor hotel reviews. The scenarios of direct and indirect NVIB were based on the definitions and exemplars provided by Azer and Alexander (2018) (see Appendix A). Also, to ensure the realism of the scenarios, prior research about hotels and restaurant reviews was consulted, which shows that 
such reviews comprise a mix of tangible features, such as the décor, fittings, fixtures and food, as well as intangible features such as service staff (Berezina et al., 2015, Sparks and Browning, 2011). To control for the content of the reviews, we kept the content similar for direct and indirect NVIB, and the only difference is the way they explicitly advise others not to transact with focal providers (direct). Scenario realism was tested using one item adapted from (Gelbrich et al., 2015): 'I think the description of the situation is realistic', and the results show that the scenarios of this experiment are realistic $(M=5.90, \mathrm{SD}=1.02)$.

\section{Manipulation Check and Measurements}

The experimental manipulations were tested using this question: 'In this review, the reviewer trying to: 1-Inform other reviewers of a terrible service experience (Indirect) 2 - Advise other reviewers explicitly not to transact with a service provider based on a terrible service experience (Direct)' The results of the manipulation checks resulted in dropping seven participants (those who failed to choose the correct answer) from each group, leaving 90 participants ( $\mathrm{N}=45 /$ group). The $x^{2}$ test for NVIB indicates different answer patterns between manipulations, $x^{2}(2)=38.11, \mathrm{p}<.001$. After reading the scenarios, participants completed a questionnaire that comprised items to measure dependent variables, manipulation checks and demographic items (gender and age) in this order to avoid biased response to dependent variables (Perdue and Summers, 1986). Following the recommendations of Fishbein (1967) and Triandis (1971), we measured attitude and behavioral intentions separately. This is based on the assumption that the extent to which individuals' feelings, cognitions towards a focal object are consistent with their behavioral intentions has underpinned the attitude-behavior debate (Triandis, 1971).

Based on previous research on e-WOM, forum credibility, recipient utilitarian value and homophily have been considered to affect the acceptance and persuasiveness of e-WOM (Ayeh et al., 2013, Babić Rosario et al., 2016, Reichelt et al., 2014). Accordingly, two confounding variables were selected: attitude towards checking online reviews (utilitarian value) and perceived forum credibility. Additionally, we controlled for the content of the review and its length as well as the homophily and deliberately hid any factor that reflected the reviewers' age, gender, nationalities or social status.

Confirmatory factor analysis (CFA) was performed on all the key scales used in this research using AMOS23 with Maximum Likelihood Estimation (Bagozzi and Yi, 1988). The 
CFA for this experiment revealed a good fit with the data $\left(\chi^{2} / d f=1.40 ; \mathrm{CFI}=.97\right.$; RMSEA $=$ 0.05). Additionally, factors loading and reliability of scales are all above the recommended threshold of 0.7 (Hair et al., 2010). Also, tests were undertaken to confirm convergent (AVE $>.5$ ) and discriminant (maximum shared variance and the average shared variance were both less than the value of the AVE) validity (Bagozzi and Yi, 1988). The square root of AVE for each construct is greater than the correlations between them and all other constructs, suggesting an adequate discriminant validity of all measurements (Fornell and Larcker, 1981). The correlations among the study constructs show no threats of multicollinearity (Hair et al., 2010) (see Appendix B).

\section{Results}

An independent samples t-test was conducted, which shows a significant difference in impact between direct and indirect NVIB, with a relative strength of direct over indirect on both attitudes $\left(M_{i}=2.94, M_{d}=1.86 ; \mathrm{p}<.001, \mathrm{t}=6.88\right)$ and behavioral intentions $\left(M_{i}=2.55, M_{d}\right.$ $=1.52 ; \mathrm{p}<.001, \mathrm{t}=7.57$ ) of other actors toward service providers (see Table 1 ). To provide an indication that the difference between the two groups did not occur by chance, Cohen's d was calculated to show a large effect size (more than 0.8 ) on both dependent variables (Cohen, 1988), thus confirming H1. To assess the effect of the confounding variables, an Analysis of Covariance (ANCOVA) was conducted, demonstrating a non-significance of the confounding variables $(\mathrm{p}>.05)$ on the two dependent variables.

Table 1: Means Values, Standard Deviations, t-Values, and Cohen's d (Study 1)

\begin{tabular}{|l|c|c|}
\hline \multirow{2}{*}{ Indirect NVIB } & \multicolumn{2}{|c|}{ Outcomes } \\
\cline { 2 - 3 } & Attitude & Behavioral Intentions \\
\hline Direct NVIB & $2.94(0.76)$ & $2.55(0.66)$ \\
\hline t- values & $1.86(0.69)$ & $1.52(0.62)$ \\
\hline Cohen's d & $6.88^{*}$ & $7.57^{*}$ \\
\hline
\end{tabular}

$* \mathbf{P}<.001$

\section{Study 2: The Moderating Role of Aggregate Ratings}

When customers read online reviews, they are not only exposed to review valence but also to the aggregate rating of a service provider, which represents a form of social influence (Gavilan et al., 2018). Aggregate rating is the average number of stars that other customers have given to this hotel or restaurant (Filieri et al., 2015), thereby representing the perceived norms of the users' network (Wu et al., 2016) and, accordingly, firms proactively induce their 
consumers to rate their products or service online (Godes and Mayzlin, 2004). Prior research reveals mixed views regarding the effect of customer ratings. Some suggest that sales revenues are affected by aggregate ratings (Reinstein and Snyder, 2005, Sawhney and Eliashberg, 1996) while others suggest that customers infer the quality of a product from the valence of online reviews only (e.g. Chen et al., 2004, Duan et al., 2008, Lee et al., 2009). Another view argues that web users trust low numerical ratings more than high ratings (Gavilan et al., 2018). Other authors claim that product ratings are more powerful in impacting a customer's purchase intention while the attitudes of customers are mainly influenced by the valence of the review (Sen and Lerman, 2007, Weinberger and Dillon, 1980).

The impact of a collective level of influence (valence and aggregate rating) is worth investigating, especially as extant studies have looked at negative valence in general but not as direct and indirect. For instance, according to prior research drawing from attribution theory, the presence of a high aggregate rating combined with negative reviews causes inconsistency in the thinking of customers (Qiu et al., 2012). To resolve this inconsistency, consumers may downplay the high aggregated rating (Sen and Lerman, 2007). However, it is not clear if this would differ from direct to indirect NVIB, especially when, according to SIT, the influence of the message relates to the tendency of customers to accept advice which explicitly exists in reviews that show direct NVIB and not in either heuristics such as aggregate ratings or reviews that show indirect NVIB. Accordingly, also based on the results of Study 1, it is adequate to argue that the moderating role of aggregate ratings will differ according to the type of NVIB, with a relative strength of direct over indirect.

\section{H2: Aggregate ratings moderate the influence of NVIB such that high aggregate ratings of service providers will ameliorate the impact of indirect NVIB but not direct NVIB on other actors' (i) attitudes and (ii) behavioral intentions towards service providers.}

\section{Design and Procedures}

This experiment tests $\mathrm{H} 2$ using a 2 (NVIB, direct and Indirect) $\times 2$ (Aggregate Ratings, High and Low) factorial design. Following the recommendation by Hair et al. (2010), a sample of 200 ( $\mathrm{N}=50$ /group) university students (females 55\%, average age $=20.10$ years, $S D=1.07)$ was recruited. We also made up the scenarios like TripAdvisor restaurant reviews (see Appendix A). Scenario realism was tested, and the results show these scenarios are found to be realistic $(M=6.20, \mathrm{SD}=1.10)$. This experiment was conducted in a fully 
controlled environment and subjects were randomly assigned using between-subjects design to the four conditions.

\section{Manipulation Check and Measurements}

The experimental manipulations were tested using the same question from Study 1 to check respondents' understanding of NVIB treatments in addition to the following question for the aggregate rating treatment: 'The aggregate (overall) rating of this restaurant is: 1High, 2- Low'. The results of the manipulation checks for NVIB were $x^{2}(2)=59.01, p<$ .001. Similarly, for the Aggregate Rating, $x^{2}(2)=35.61, p<.001$, dropping four participants to leave 196 participants ( $\mathrm{N}=49$ /group). The measures had good reliability and the CFA revealed an acceptable fit $\left(\chi^{2} / d f=2.0 ; \mathrm{CFI}=.93 ; \mathrm{RMSEA}=0.07\right)$. Tests were undertaken to confirming convergent and discriminant validity (Bagozzi and Yi, 1988); also, correlations among the study constructs showed no threats of multicollinearity (see Appendix B).

\section{Results}

After satisfying the preliminary checks of the assumption of homoscedasticity (Levene's Test $p>.05$ ), the equality of the entire variance-covariance matrices (Box's Test $p=.651$ ), MANCOVA was conducted. The results reveal a significant interaction effect between NVIB and aggregate rating $\left(\right.$ Wilk's lambda $\left.=.81, F(2,111)=12.7, \mathrm{p}<.001, \eta^{2}=.186\right)$ and any effects for the confounding variables were non-significant. The interaction was significant for attitude $\left(F(1,112)=23.42, \mathrm{p}<.001, \eta^{2}=.173\right)$ and behavioral intentions $(F(1,112)=$ 21.63, $\mathrm{p}<.001, \eta^{2}=.162$ ). As seen in Table 2 and Figure 1 , both direct and indirect NVIB had negative effects on other actors' attitudes and behavioral intentions. However, in case the restaurant had a high aggregate rating, indirect NVIB had less negative impact than direct NVIB on other actors' attitudes $\left(M_{i}=3.6, M_{d}=1.28 ; \mathrm{p}<.001\right)$ and behavioral intentions $\left(M_{i}=3.32, M_{d}=1.52 ; \mathrm{p}<.001\right)$. Similarly, with low aggregate rating, direct NVIB shows a greater negative effect than indirect NVIB (Attitudes: $M_{d}=1.00, M_{i}=1.43 ; \mathrm{p}<.001$; Behavioral intentions: $\left.M_{d=1.11}, M_{i}=1.45 ; \mathrm{p}<.001\right)$. Therefore, no matter how high or low the aggregate rating direct NVIB consistently had a greater negative effect than indirect NVIB. The moderating role of high aggregate ratings is clearly seen in the slightly favorable results on customers exposed to indirect NVIB, but not on those exposed to direct NVIB. Thus, H2 is confirmed. 
Table 2: Means of significant interaction effect $(\mathbf{p}<.001)$ on dependent variables (Study 2)

\begin{tabular}{|c|c|c|c|c|c|}
\hline & NVIB & $\begin{array}{c}\text { Aggregate } \\
\text { Rating }\end{array}$ & Means & SD & $\mathbf{N}$ \\
\hline \multirow[t]{4}{*}{ Attitude } & \multirow[t]{2}{*}{ Indirect } & High & 3.06 & 1.31 & 49 \\
\hline & & Low & 1.43 & .541 & 49 \\
\hline & \multirow[t]{2}{*}{ Direct } & High & 1.28 & .535 & 49 \\
\hline & & Low & 1.00 & .000 & 49 \\
\hline \multirow{4}{*}{$\begin{array}{c}\text { Behavioral } \\
\text { Intention }\end{array}$} & \multirow[t]{2}{*}{ Indirect } & High & 3.32 & 1.31 & 49 \\
\hline & & Low & 1.45 & .638 & 49 \\
\hline & \multirow[t]{2}{*}{ Direct } & High & 1.52 & .837 & 49 \\
\hline & & Low & 1.11 & .312 & 49 \\
\hline
\end{tabular}
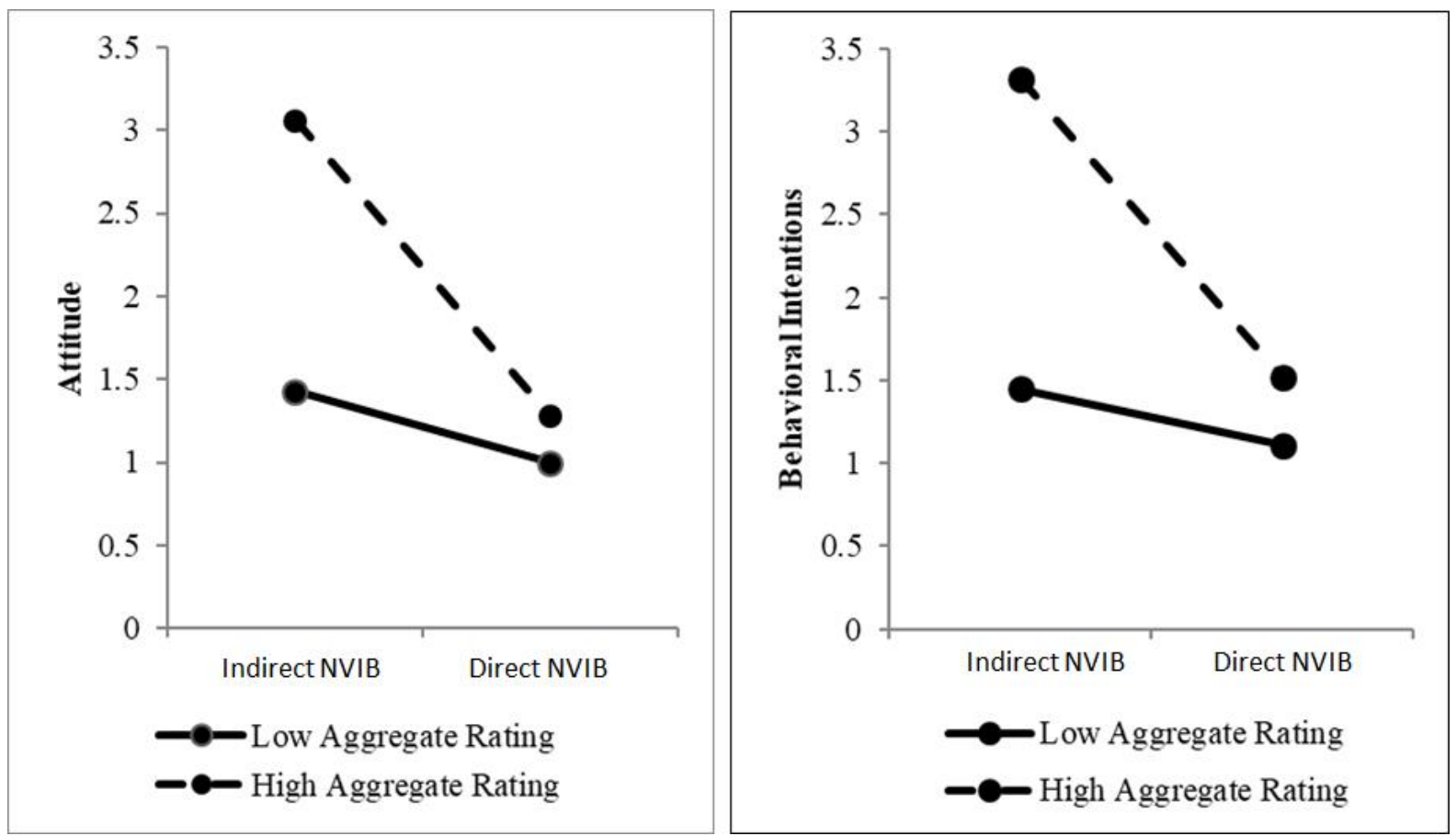

Figure 1: Interaction Effect for Dependent Variables - Study 2

\section{Study 3: The Moderating Role of Volume of Positive Reviews}

Customers are usually exposed to both positive and negative reviews about the same provider. According to previous research, customers are inclined to specifically seek negative reviews for being more diagnostic and informative (Berezina et al., 2015), with the reviews having a stronger influence on other actors than positive ones (Park and Lee, 2009). These assumptions, according to social psychology research, are justified by the notion of 'negativity bias', which advocates the potency and dominance of negative compared to positive events (Rozin and Royzman, 2001). Nevertheless, other views argue that it is the volume of reviews that matters (Babić Rosario et al., 2016, Berger et al., 2010, Wirtz et al., 2013 ) and that a small number of negative reviews might serve to promote the credibility of a 
website or a review site (Doh and Hwang, 2009). However, these studies consider negative reviews as homogenous rather than as direct and indirect NVIB. Customers tend to make product-related attributions for negative reviews and non-product attributions for positive ones so as to minimize risk and avoid potential losses, which may lead to a less salient effect of volumes of positive reviews (Sen and Lerman, 2007). Importantly, Study 2 shows the relative strength of direct compared to indirect NVIB, even when combined with positive aggregate rating. Therefore, with reference to prior research about the persuasive nature of injunctive compared to descriptive messages (Lee et al., 2008, Schultz et al., 2008) and to the acceptance of explicit advice based on SIT, we expect the power of negative over volume of positive reviews to show more with direct compared to indirect NVIB. The third experiment of this paper approaches the volume-valence debate by looking at not only the higher volume of positive reviews but also the equal volume to direct and indirect NVIB and hypothesizes that:

\section{H3: Volumes of positive reviews moderate the impact of NVIB such that a higher volume of positive reviews will ameliorate the impact of indirect but not direct NVIB on other actors'(i) attitudes and (ii) behavioral intentions towards service providers.}

\section{Design and Procedures}

This experiment tests $\mathrm{H} 3$ using a $2(\mathrm{NVIB}$, direct and indirect) $\times 2$ (volume of positive reviews, equal and higher) factorial design resulting in four scenarios (see Appendix A). Recent market research shows that customers usually check four to twelve reviews before booking a hotel (TripAdvisor.co.uk 2016). Thus, considering respondent fatigue, this study in the equal reviews' treatment, provided respondents with one positive vs. one negative review and a maximum of four reviews (three positive and one negative) in the higher volume treatment. A sample of 220 individuals (cell size $=55$, females $50.8 \%$, average age $=40$ years, $S D=1.23$ ) was recruited via MTurk. Using the randomization facility provided by Qualtrics, participants were assigned randomly to conditions using a between-subjects design. The scenario realism was tested using the same item and the results show that the scenarios are realistic $(\mathrm{M}=5.92, S D=1.15)$.

\section{Manipulation Check and Measurements}

The same questions were used to check respondents' understanding of NVIB treatments in addition to the following question for positive reviews volume: 'The number of positive reviews is .... negative reviews: 1- Higher than 2- Equal to'. The results of the manipulation 
checks for NVIB were $x^{2}(2)=39.01, p<.001$. Similarly, for the positive reviews, they were $x^{2}(1)=55.61, p<.001$, leaving 200 participants ( $\mathrm{N}=50 /$ group). The measures had good reliability and the CFA revealed a good fit $\left(\chi^{2} / d f=1.90 ; \mathrm{CFI}=.98 ; \mathrm{RMSEA}=0.03\right)(\mathrm{Hu}$ and Bentler, 1995). Tests were undertaken to confirm the convergent and discriminant validity (Bagozzi and Yi, 1988); also, correlations among the study constructs showed no threats of multicollinearity (see Appendix B).

\section{Results}

After satisfying the preliminary checks of the assumption of homoscedasticity (Levene's Test $p>.05)$, the equality of the variance-covariance matrices (Box's Test $p=.153$ ), MANCOVA was conducted. The results reveal a significant interaction effect between NVIB and volume of positive reviews (Wilk's lambda $=.68, F(2,195)=47.83, \mathrm{p}<.001, \eta^{2}=$ .329), and no significant effect was found for the confounding variables. The interaction was significant for attitude $\left(F(1,196)=87.98, \mathrm{p}<.001, \eta^{2}=.310\right)$ and behavioral intentions $(F$ $\left.(1,196)=43.43, \mathrm{p}<.001, \eta^{2}=.181\right)$. As seen in Table 3 and Figure 2, both direct and indirect NVIB have negative effects on other actors' attitudes and behavioral intentions. However, in the case of a high volume of positive reviews, indirect NVIB has less negative impact than direct NVIB on other actors' attitudes $\left(M_{i}=2.84, M_{d}=1.08 ; \mathrm{p}<.001\right)$ and behavioral intentions $\left(M_{i}=2.97, M_{d}=1.10 ; \mathrm{p}<.001\right)$. Also, on equal volumes of positive and negative reviews, direct NVIB has stronger negative impact than indirect NVIB (Attitudes: $M_{d}=1.247, M_{i}=1.673 ; \mathrm{p}<.001$; Behavioral intentions: $\left.M_{d}=1.02, M_{i}=1.973 ; \mathrm{p}<.001\right)$. Therefore, $\mathrm{H} 3$ is confirmed as volumes of positive reviews moderate the impact of NVIB such that a higher volume of positive reviews ameliorates the impact of indirect but not direct NVIB on attitudes and behavioral intentions of other actors toward service providers. Although, attitudes of other actors exposed to direct NVIB were even more negative when exposed to higher $\left(M_{d}=1.08\right)$ than equal volumes of positive reviews $\left(M_{d}=1.247\right)$. In both cases the mean score is very low; thus, the observed difference is merely due to chance. Specifically, such an impact did not show in the behavioral intentions scores, which are more negative with equal $\left(M_{d}=1.02\right)$ than higher volumes of positive reviews $\left(M_{d}=1.10\right)$. 
Table 3: Means of significant interaction effect $(\mathrm{P}<.001)$ on dependent variables (Study 3)

\begin{tabular}{|c|c|c|c|c|c|}
\hline $\begin{array}{c}\text { Dependent } \\
\text { Variables }\end{array}$ & NVIB & $\begin{array}{l}\text { Volume of } \\
\text { Positive } \\
\text { Reviews }\end{array}$ & Means & SD & $\mathbf{N}$ \\
\hline \multirow{4}{*}{ Attitudes } & \multirow{2}{*}{ Indirect } & Higher & 2.847 & .756 & 50 \\
\hline & & Equal & 1.673 & .423 & 50 \\
\hline & \multirow{2}{*}{ Direct } & Higher & 1.080 & .247 & 50 \\
\hline & & Equal & 1.247 & .553 & 50 \\
\hline \multirow{4}{*}{$\begin{array}{l}\text { Behavioral } \\
\text { Intentions }\end{array}$} & \multirow{2}{*}{ Indirect } & Higher & 2.967 & .726 & 50 \\
\hline & & Equal & 1.973 & .574 & 50 \\
\hline & \multirow{2}{*}{ Direct } & Higher & 1.100 & .287 & 50 \\
\hline & & Equal & 1.020 & .141 & 50 \\
\hline
\end{tabular}
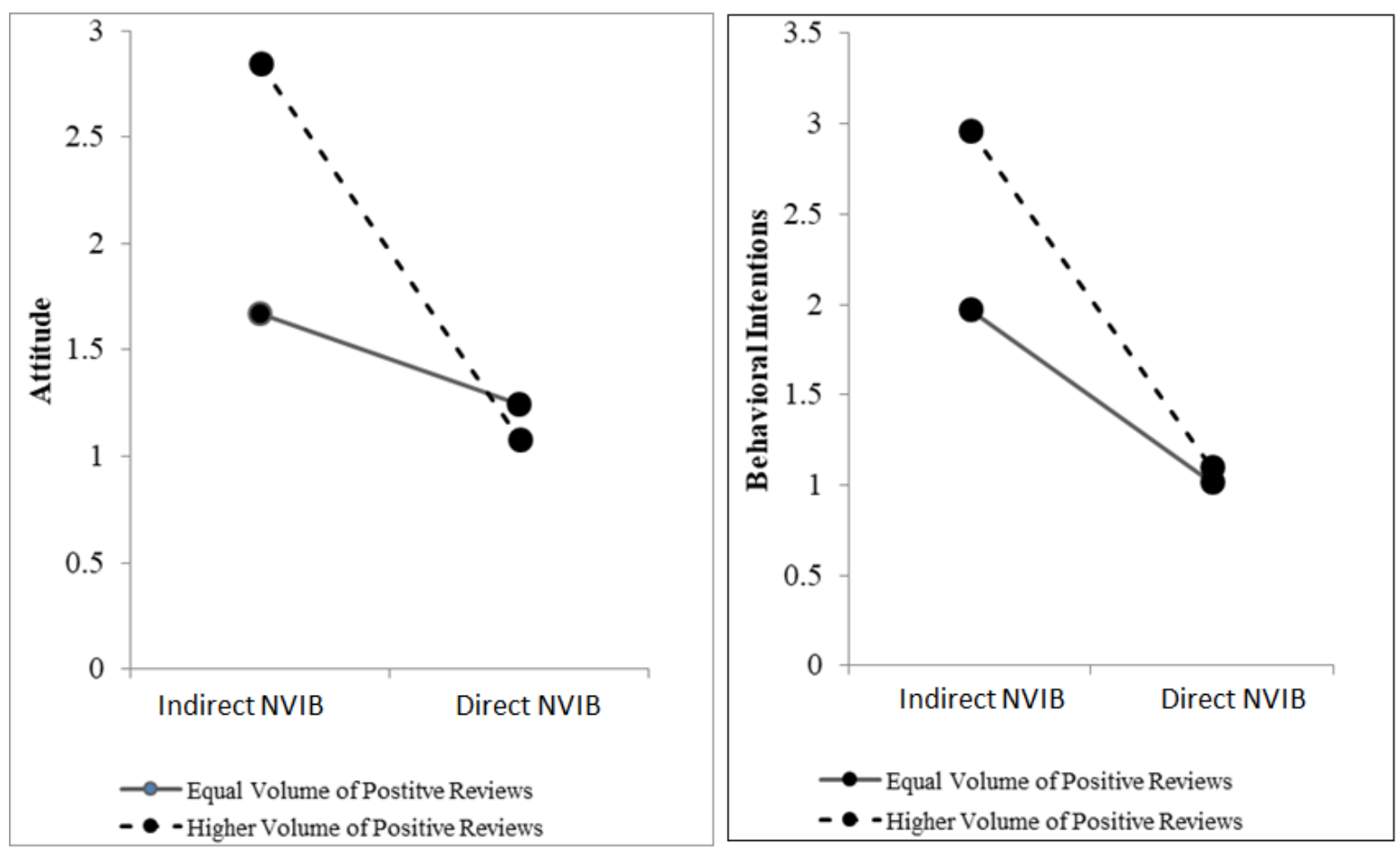

Figure 2: Interaction Effect for Dependent Variables - Study 3

\section{Study 4: The Moderating Role of Managerial Responses}

The issue as to whether the provision of a response to a negative online review positively affects the inferences other actors draw about service providers is far from settled (Sparks et al., 2016) notwithstanding its role in the impact of direct compared to indirect NVIB. Some views argue that managerial response to negative reviews can have a negative effect on hotel performance (Mudambi and Schuff, 2010, Van Noort and Willemsen, 2012) and on customers' behavioral outcomes towards service providers (Mauri and Minazzi, 2013). However, non-action strategies may allow negative information about service providers to stand unchallenged, thereby potentially damaging their image (Sparks et al., 2016, Xie et al., 
2016). Nevertheless, a few studies advocate the provision of managerial response to negative reviews as it may help restore a positive image (Lee and Song, 2010), specifically reducing the likelihood of other actors on third-party platforms drawing their own negative inferences about focal service providers (Sparks and Bradley, 2014). However, these studies have examined negatively valenced reviews as merely negative, without taking into consideration the difference in impact between direct and indirect NVIB. Hence, the moderating role of managerial response to direct and indirect NVIB is unclear. In agreement with prior studies that favor the provision of managerial response, we argue that a managerial response (versus no response) will have a favorable impact on other actors' attitudes and behavioral intentions. However, this impact may differ based on the relative strength of direct compared to indirect, as demonstrated in the results of the studies of this paper thus far.

H4: The provision of managerial responses will moderate the impact of both direct and indirect NVIB on other actors' (i) attitudes and (ii) behavioral intentions towards service providers; however, this impact is more favorable with indirect than direct NVIB.

\section{Design and Procedures}

This experiment tests $\mathrm{H} 4$ using a $2(\mathrm{NVIB}$, direct $\&$ indirect) $\times 2$ (Managerial response, response \& no response) factorial design, resulting in four scenarios (see Appendix A). The scenario of managerial response was adapted from the commonly used one by managers on TripAdvisor. Following the recommendations of Hair et al. (2010) for sample size requirements, a sample of 220 individuals (cell size $=55$, females $58.3 \%$, average age $=36$ years, $S D=1.18$ ) was recruited through Prolific, an alternative to MTurk. This online subject pool offers a source of reliable data that is representative of the general population (Hazée et $a l ., 2019)$. The scenario realism was tested and shows that the scenarios are realistic $(\mathrm{M}=6.25, S D=1.10)$.

\section{Manipulation Check and Measurements}

The same questions were used to check respondents' understanding of NVIB treatments in addition to the following question for managerial response: 'The managers of this restaurant to this negative review: 1-responded 2-did not respond. The results of the manipulation checks for NVIB were $x^{2}(2)=40.5, p<.001$. Similarly, for managerial response, they were $x^{2}(2)=48.3, p<.001$, leaving 216 participants $(\mathrm{N}=54 /$ group $)$. As the response of service providers was tested in this experiment, in addition to the confounding variables used in the studies of this paper, another confounding variable, namely, blame 
attribution adapted from Gelbrich (2010) was added. This variable captures the attribution of other actors of the responsibility of the service providers and their control over the situation. The measures had good reliability and the CFA revealed a good fit $\left(\chi^{2} / d f=1.95 ; \mathrm{CFI}=.95\right.$; RMSEA = 0.02) $(\mathrm{Hu} \&$ Bentler, 1995). Tests were undertaken to confirm convergent and discriminant validity (Bagozzi and Yi, 1988); also, correlations among the study constructs show no threats of multicollinearity (see Appendix B).

\section{Results}

After satisfying the preliminary checks of the assumption of homoscedasticity (Levene's Test $p>.05$ ), the equality of the variance-covariance matrices (Box's Test $p=.810$ ), MANCOVA was conducted. The results reveal a significant interaction effect between NVIB and managerial response (Wilk's lambda $\left.=.893, F(2,205)=12.296, \mathrm{p}<.001 \eta^{2}=.107\right)$, and no significant effect was found for the confounding variables. The interaction was significant for attitude $\left(F(1,206)=23.29, \mathrm{p}<.001, \eta^{2}=.102\right)$ and behavioral intentions $(F$ $\left.(1,206)=11.622, \mathrm{p}<.001, \eta^{2}=.053\right)$. As seen in Table 4 and Figure 3, the managerial response moderated the impact of both direct and indirect NVIB showing a significant difference in their impact $(\mathrm{p}<.001)$ on other actors' attitudes and behavioral intentions. When managers respond to negative reviews, it results in less negative impact of both direct and indirect NVIB on other actors' attitudes $\left(M_{i}=3.357, M_{d}=3.000 ; \mathrm{p}<.001\right)$ and behavioral intentions $\left(M_{i}=3.802, M_{d}=3.180 ; \mathrm{p}<.001\right)$ than when they do not respond (attitudes: $M_{i}=2.453, M_{d}=1.125 ; \mathrm{p}<.001$; behavioral intentions: $\left.M_{i}=2.501, M_{d}=1.123 ; \mathrm{p}<.001\right)$. Yet, as shown in the mean scores, the role of managerial response versus no response resulted in a more favorable outcome with indirect compared to direct NVIB. Thus, H4 is confirmed.

Table 4: Means of significant interaction effect $(\mathrm{P}<.001)$ on dependent variables (Study 4)

\begin{tabular}{|c|c|c|c|c|c|}
\hline $\begin{array}{c}\text { Dependent } \\
\text { Variables }\end{array}$ & NVIB & $\begin{array}{c}\text { Managerial } \\
\text { Response }\end{array}$ & Means & SD & $\mathbf{N}$ \\
\hline \multirow{4}{*}{ Attitudes } & \multirow{2}{*}{ Indirect } & Response & 3.357 & 1.35 & 54 \\
\hline & & No Response & 2.453 & 1.20 & 54 \\
\hline & \multirow{2}{*}{ Direct } & Response & 3.000 & 1.16 & 54 \\
\hline & & No response & 1.125 & .318 & 54 \\
\hline \multirow{4}{*}{$\begin{array}{l}\text { Behavioral } \\
\text { Intentions }\end{array}$} & \multirow{2}{*}{ Indirect } & Response & 3.802 & 1.34 & 54 \\
\hline & & No Response & 2.501 & 1.15 & 54 \\
\hline & \multirow{2}{*}{ Direct } & Response & 3.180 & 1.16 & 54 \\
\hline & & No response & 1.123 & 1.02 & 54 \\
\hline
\end{tabular}



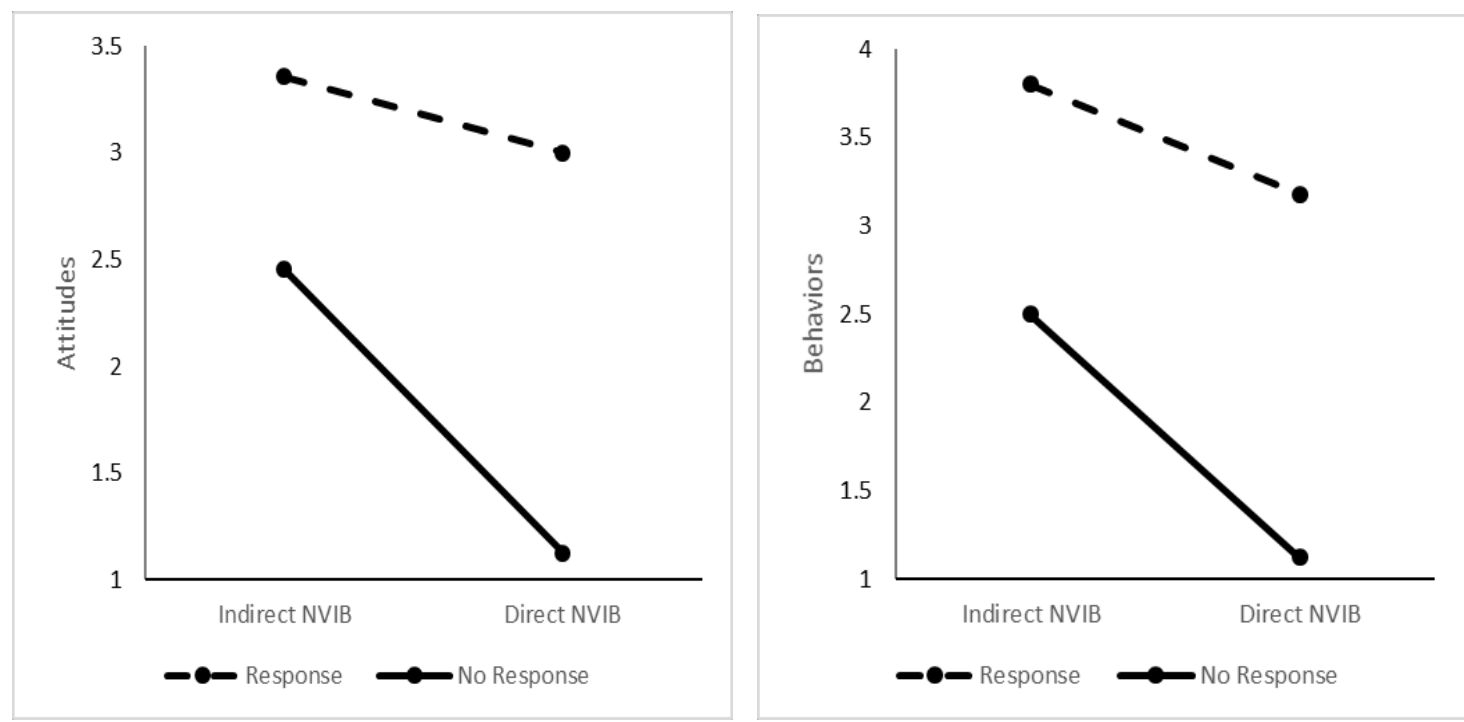

Figure 3: Interaction Effect for Dependent Variables - Study 4

\section{General Discussion}

\section{Theoretical Implications}

This paper advances empirical research on negative CEB and it represents one of the first studies to measure the impact of both indirect and direct NVIB. Secondly, in opposition to the majority of the extant studies, which limit the influence of customers on other customers to directly recommending service providers or warning others from transacting with focal providers (cf. Blazevic et al., 2013, Jaakkola and Alexander, 2014, Kumar et al., 2010), this paper shows that customers' influence extends to include indirect NVIB. Thirdly, this paper shows the different ways that customers attempt to have a negative influence on other customers and provides new insights into the moderating roles of high and low aggregate ratings, equal and higher volume of positive reviews and managerial responses on the influence of both direct and indirect NVIB. Thus, this research contributes to online reviews research with insights which transcend the aggregate impact of negative reviews, thereby responding to calls by several e-WOM studies (e.g. Balaji et al., 2016, Hennig-Thurau et al., 2010, King et al., 2014) by providing empirical results that demonstrate the significant difference in the impact of direct and indirect NVIB with a relative strength of direct NVIB displayed. Moreover, the results contribute to SIT by providing empirical results that show even minimal difference in the way customers exert influence via direct and indirect NVIB have a significant effect on other actors' evaluations (Cohen and Golden, 1972). 
The results reveal that high aggregate ratings ameliorate the impact of indirect NVIB, which is different to prior studies that claim no impact from aggregate rating (e.g. Duan et al., 2008, Lee et al., 2008, Lee et al., 2009) or those that claim travelers put their trust in low rather than high ratings (Gavilan et al., 2018). Importantly, high ratings did not ameliorate the impact of direct NVIB, which shows a consistent negative impact on others even when service providers are given excellent aggregate ratings. Thus, in opposition to studies that examined negative reviews as being merely negative with an aggregate negative impact, this paper shows a significant difference in this impact, showing the relative strength of direct over indirect. This is a new approach for investigating online reviews and, when applied in future research, is expected to enhance e-WOM literature, especially in terms of the contrast in the extant findings.

Similarly, this study provides new insights into the volume-valence debate, with studies advocating a stronger impact of volumes of positive compared to negative reviews (e.g. Babić Rosario et al., 2016, Berger et al., 2010, Liu and Park, 2015, Wirtz et al., 2013) and the opposite (Ba and Pavlou, 2002, Hollebeek and Chen, 2014). The results show that higher volumes of positive reviews ameliorate the negative impact of indirect, but not of direct, NVIB, which demonstrates a consistent negative impact on others' attitudes and behaviors, even when juxtaposed with higher volumes of positive reviews. This study extends previous research findings by revealing that not all negative reviews have the same impact when accompanied by positive reviews. Prior research shows that a few negative messages might serve to promote the credibility of a website or a review site (Doh and Hwang, 2009) since it is the number of positive reviews that matters (Babić Rosario et al., 2016, Berger et al., 2010, Wirtz et al., 2013), instead, our results reveal that it is the relative strength of NVIB that matters. In other words, NVIB within online reviews could be direct or indirect, with a difference in their negative impact; hence, an aggregate view of negative impact is no longer useful.

Finally, this paper provides new insights into the moderating role of managerial response to negative reviews. Although previous research advocates the provision of response (cf. Sparks and Bradley, 2014, Sparks et al., 2016, Xie et al., 2016), these studies have studied negatively valenced reviews as merely negative, with no consideration given for the difference in impact between direct and indirect NVIB. Our study is the first to compare the impact of the provision of response versus no response to direct and indirect NVIB. The 
results show that managerial response mitigates the impact of both direct and indirect NVIB and reduces the likelihood of other actors on third-party platforms drawing their own negative inferences about focal service providers.

\section{Managerial Implications}

This paper enhances the managerial understanding of the impact of customers' NVIB in online social networks by showing differences in the impact of direct and indirect NVIB. Accordingly, we recommend that managers differentiate between these two categories and not to conceive them as homogenous. Additionally, to consider in their mitigating strategies not only what customers say in their negative reviews or comments about their services, products or brands but also how they say it. In their negative reviews, customers may or may not explicitly advise others not to transact with focal service providers. Evident in the results of this paper, this difference in the way customers write their negative reviews, even if minimal, can have a significant effect on other actors' attitudes and behavioral intentions toward service providers.

Importantly, service providers are not recommended to rely solely on given aggregate ratings; even excellent aggregate ratings do not result in a favorable impact on other actors exposed to direct NVIB. Likewise, it is highly recommended that managers should not neglect the impact of a single negative review, especially if it shows direct NVIB. Therefore, managers are recommended to develop strategies to prioritize the handling of direct NVIB. It is recommended that managers use semantic tools to detect direct NVIB early on. Semantic tools can help managers to pay attention to what customers say about their products, services or brands. For example, semantic tools can monitor exhortations such as 'Don't go there, Don't eat there....etc.' to detect direct NVIB. Additionally, third party e-retailers may provide service providers with a way to develop an algorithm to detect direct NVIB as a response is likely to be critical. This is to prevent other social actors in the online network from drawing their own negative inferences about this service provider as seen in the results of this paper regarding providing versus not providing managerial response to direct NVIB.

\section{Limitations and Further Research}

Despite the implications indicated above, the limitations of this study also offer the potential for future research in this area. Future research could replicate this study using other 
online forums. It was an advantage that the reviews did not show the nationality, age, name, social status, gender or personal pictures of the reviewers to eliminate any confounding of homophily. Future research might consider manipulating these factors. Considering the respondents fatigue the scenarios for the equal volume of reviews were one negative vs. one positive review while the higher volume scenarios were one negative vs. three positive reviews. Future research may replicate this study by increasing the number of reviews under both conditions. Following the extant NVIB classification, this paper used the most frequently used two forms of NVIB by online reviewers on TripAdvisor, namely, dissuading and discrediting, to represent direct and indirect NVIB (Azer and Alexander, 2018). Future research could replicate our study to investigate the impact of other forms of NVIB that show emotional (regretting form), sarcastic (deriding form) or severe (warning/endorsing competitors forms) nuances and compare their impact to functional forms (i.e. discrediting and dissuading forms).

To control for the review content, we kept scenarios of direct and indirect the same except for the explicit advice that exists in direct and not in indirect NVIB. Assuming that the level of negativity can vary from low to high, future research may investigate the impact of direct vs. indirect NVIB with different review content (e.g. direct NVIB with less details than indirect NVIB). Additionally, in our paper we kept the level of service provider controllability over the underlying problems the same for both direct and scenarios. Future research may consider attribution of blame and/or controllability of service providers as it is possible that direct NVIB will have relatively lower impact in situations in which the service provider had little or no control over the underlying problem.

Our research used managerial response adapted from that commonly used by managers on TripAdvisor; future research may manipulate tailored managerial response. Importantly, this paper provides results about differences in the negative impact of direct and indirect NVIB moderated by higher and equal volume of juxtaposed positive reviews. Given the absence of such classification in positively valenced influencing behavior (PVIB) it is recommended that future research provide a typology of PVIB and study its moderating role on the impact of direct and indirect NVIB. Moreover, to advance research on CEB, future research may apply this direct-indirect classification to study its other three forms: codeveloping, augmenting and mobilizing behavior (Jaakkola and Alexander, 2014). 


\section{References}

Albrecht, A., Walsh, G. and Beatty, S. (2016), "Perceptions of Group Versus Individual Service Failures and Their Effects on Customer Outcomes", Journal of Service Research, Vol. 20 No. 2, pp. 188-203.

Alexander, M., Jaakkola, E. and Hollebeek, L. (2018), "Zooming out: actor engagement beyond the dyadic", Journal of Service Management, Vol. 29 No. 3, pp. 333-351.

Ayeh, J., Au, N. and Law, R. (2013), "Do We Believe in TripAdvisor?" Examining Credibility Perceptions and Online Travelers' Attitude toward Using User-Generated Content", Journal of Travel Research, Vol. 52 No. 4, pp. 437-452.

Azer, J. (2015), "Facebook from socializing to advertising: an empirical study on the effect of Facebook as an advertising tool", African Journal of Business Management, Vol. 9 No. 24, pp. 796-813.

Azer, J. and Alexander, M. (2017), "Negatively-valenced Customer Engagement Behavior: Forms and Drivers", in Gummesson, E., Mele, C. and Polese, F. (eds), 5th Naples Forum on Service: 6-9 June 2017., Naples, Italy, p. 7.

Azer, J. and Alexander, M. (2018), "Conceptualizing negatively valenced influencing behavior: forms and triggers", Journal of Service Management, Vol. 29 No. 3, pp. 468-490.

Azer, J. and Alexander, M. (2020), "Negative customer engagement behaviour: the interplay of intensity and valence in online networks", Journal of Marketing Management, Vol. 36 No. 34, pp. 361-383.

Ba, S. and Pavlou, P. (2002), "Evidence of the Effect of Trust Building Technology in Electronic Markets: Price Premiums and Buyer Behavior", MIS Quarterly, Vol. 26 No. 3, pp. 243-268.

Babić Rosario, A., Sotgiu, F., De Valck, K. and Bijmolt, T. (2016), "The effect of electronic word of mouth on sales: A meta-analytic review of platform, product, and metric factors", Journal of Marketing Research, Vol. 53 No. 3, pp. 297-318.

Bagozzi, R. and Yi, Y. (1988), "On the evaluation of structural equation models", Journal of the Academy of Marketing Science, Vol. 16 No. 1, pp. 74-94.

Balaji, M. S., Khong, K. W. and Chong, A. Y. L. (2016), "Determinants of negative word-of-mouth communication using social networking sites", Information \& Management, Vol. 53 No. 4, pp. 528-540.

Bansal, H. and Taylor, S. (1999), "The Service Provider Switching Model (SPSM): A Model of Consumer Switching Behavior in the Services Industry", Journal of Service Research, Vol. 2 No. 2, pp. 200-218.

Berezina, K., Bilgihan, A., Cobanoglu, C. and Okumus, F. (2015), "Understanding Satisfied and Dissatisfied Hotel Customers: Text Mining of Online Hotel Reviews", Journal of Hospitality Marketing \& Management, Vol. 25 No. 1, pp. 1-24.

Berger, J., Sorensen, A. and Rasmussen, S. (2010), "Positive effects of negative publicity: When negative reviews increase sales", Marketing Science, Vol. 29 No. 5, pp. 815-827.

Blasco-Arcas, L., Hernandez-Ortega, B. and Jimenez-Martinez, J. (2014), "The online purchase as a context for co-creating experiences. Drivers of and consequences for customer behavior", Internet Research, Vol. 24 No. 3, pp. 393-412.

Blazevic, V., Aksoy, L., van Riel, A., Kandampully, J., Hammedi, W., Garnefeld, I., Rust, R., Keiningham, T., Andreassen, T. and Donthu, N. (2013), "Beyond traditional word-of-mouth: an expanded model of customer-driven influence", Journal of Service Management, Vol. 24 No. 3, pp. 294313.

Book, L. A., Tanford, S. and Chen, Y.-S. (2016), "Understanding the Impact of Negative and Positive Traveler Reviews", Journal of Travel Research, Vol. 55 No. 8, pp. 993-1007.

Bowden, J., Conduit, J., Hollebeek, L., Luoma-aho, V. and Solem, B. A. (2017), "Engagement valence duality and spillover effects in online brand communities", Journal of Service Theory and Practice, Vol. 27 No. 4, pp. 877-897. 
Brady, M., Voorhees, C., Cronin, J. and Bourdeau, B. (2006), "The good guys don't always win: the effect of valence on service perceptions and consequences", Journal of Services Marketing, Vol. 20 No. 2, pp. 83-91.

Brodie, R. J., Fehrer, J. A., Jaakkola, E. and Conduit, J. (2019), "Actor Engagement in Networks: Defining the Conceptual Domain", Journal of Service Research, Vol. 22 No. 2, pp. 173-188.

Burnkrant, R. and Cousineau, A. (1975), "Informational and normative social influence in buyer behavior", Journal of Consumer Research, Vol. 2 No. 3, pp. 206-215.

Chen, P., Wu, S. and Yoon, J. (2004), "The impact of online recommendations and consumer feedback on sales", in Proceedings of the International Conference on Information Systems, pp. 711-724.

Cheung, C. and Thadani, D. (2012), "The impact of electronic word-of-mouth communication: A literature analysis and integrative model", Decision Support Systems, Vol. 54 No. 1, pp. 461470.

Choi, S., Mattila, A. S., Van Hoof, H. B. and Quadri-Felitti, D. (2016), "The Role of Power and Incentives in Inducing Fake Reviews in the Tourism Industry", Journal of Travel Research, Vol. 56 No. 8, pp. 975-987.

Cohen, J. and Golden, E. (1972), "Informational Social Influence and Product Evaluation", Journal of Applied Psychology, Vol. 56 No. 1, pp. 54-59.

Cohen, W. (1988), Statistical Power Analysis for the Behavioral Sciences, Lawrence Erlbaum Associates., Hillsdale, NJ.

Cronin, J. and Taylor, S. (1992), "Measuring Service Quality: A Reexamination and Extension", Journal of Marketing, Vol. 56 No. 3, p. 55.

Doh, S. and Hwang, J. (2009), "How consumers evaluate e-WOM (electronic word-of-mouth) messages", Cyber Psycholology \& Behaviour, Vol. 12 No. 2, pp. 193-7.

Dolan, R., Seo, Y. and Kemper, J. (2019), "Complaining practices on social media in tourism: A value co-creation and co-destruction perspective", Tourism Management, Vol. 73, pp. 35-45.

Donthu, N. and Gilliland, D. (1996), "The Infomercial Shopper", Journal of Advertising Research, Vol. 36 No. 2, pp. 69-76.

Duan, W., Gu, B. and Whinston, A. (2008), "Do online reviews matter? - An empirical investigation of panel data", Decision Support Systems, Vol. 45 No. 4, pp. 1007-1016.

Filieri, R., Alguezaui, S. and McLeay, F. (2015), "Why do travelers trust TripAdvisor? Antecedents of trust towards consumer-generated media and its influence on recommendation adoption and word of mouth", Tourism Management, Vol. 51, pp. 174-185.

Filieri, R. and McLeay, F. (2014), "E-WOM and Accommodation", Journal of Travel Research, Vol. 53 No. 1, pp. 44-57.

Fishbein, M. (1967), "Attitude and Prediction of Behaviour", in Fishbein, M. (Ed.) Readings in Attitude Theory and Measurement, Wiley, Oxford, pp. 477-492.

Fishbein, M. and Ajzen, I. (1975), Belief, Attitude, Intention, and Behaviour: An Introduction to Theory and Research, Addison-Wesley., Reading, MA.

Folkes, V. and Kotsos, B. (1986), "Buyers and Sellers explanations for product failure: who done it?", Journal of Marketing, Vol. 50 No. 2, pp. 74-80.

Fornell, C. and Larcker, D. (1981), "Evaluating Structural Equation Models with Unobservable Variables and Measurement Error", Journal of Marketing Research, Vol. 18 No. 1, pp. 39-50.

Gavilan, D., Avello, M. and Martinez-Navarro, G. (2018), "The influence of online ratings and reviews on hotel booking consideration", Tourism Management, Vol. 66, pp. 53-61.

Gelbrich, K. (2010), "Anger, Frustration, and Helplessness after Service Failure: Coping Strategies and Effective Informational Support", Journal of the Academy of Marketing Science, Vol. 38 No. 5, pp. 567-585.

Gelbrich, K., Gäthke, J. and Grégoire, Y. (2015), "How Much Compensation Should a Firm Offer for a Flawed Service? An Examination of the Nonlinear Effects of Compensation on Satisfaction", Journal of Service Research, Vol. 18 No. 1, pp. 107-123. 
Godes, D. and Mayzlin, D. (2004), "Using Online Conversations to Study Word-of-Mouth Communication", Marketing Science, Vol. 23 No. 4, pp. 545-560.

Hair, J., Black, W., Babin, B. and Anderson, R. (2010), Multivariate Data Analysis: A Global Perspective, Pearson., Upper Saddle, NJ.

Harmeling, C., Moffett, J., Arnold, M. and Carlson, B. (2017), "Toward a theory of customer engagement marketing", Journal of the Academy of Marketing Science, Vol. 45 No. 3, pp. 312-335.

Hazée, S., Van Vaerenbergh, Y., Delcourt, C. and Warlop, L. (2019), "Sharing Goods? Yuck, No! An Investigation of Consumers' Contamination Concerns About Access-Based Services", Journal of Service Research, Vol. 22 No. 3, pp. 256-271.

Hennig-Thurau, T., Malthouse, E. C., Friege, C., Gensler, S., Lobschat, L., Rangaswamy, A. and Skiera, B. (2010), "The Impact of New Media on Customer Relationships", Journal of Service Research, Vol. 13 No. 3, pp. 311-330.

Högström, C., Rosner, M. and Gustafsson, A. (2010), "How to create attractive and unique customer experiences: An application of Kano's theory of attractive quality to recreational tourism", Marketing Intelligence \& Planning, Vol. 28 No. 4, pp. 385-402.

Hollebeek, L. and Chen, T. (2014), "Exploring positively- versus negatively-valenced brand engagement: a conceptual model", Journal of Product \& Brand Management, Vol. 23 No. 1, pp. 62-74.

Hollebeek, L., Conduit, J., Sweeney, J., Soutar, G., Karpen, I., Jarvis, W. and Chen, T. (2016), "Epilogue to the Special Issue and reflections on the future of engagement research", Journal of Marketing Management, Vol. 32 No. 5-6, pp. 586-594.

Jaakkola, E. and Alexander, M. (2014), "The role of customer engagement behavior in value cocreation", Journal of Service Research, Vol. 17 No. 3, pp. 247-261.

Jiang, J., Gretzel, U. and Law, R. (2010), "Do negative experiences always lead to dissatisfaction?testing attribution theory in the context of online travel reviews.", in Gretzel, U., Law, R. and Fuchs, M. (eds), Information and communication technologies in tourism, Lugano, Switzerland, pp. 297-308.

Juric, B., Smith, S. and Wilks, G. (2016), "Negative customer brand engagement: an overview of conceptual and blog-based findings", in brodie, R., Hollebeek, L. and Conduit, J. (Eds.) Customer engagement: Contemporary issues and challenges, Routledge, New Zealand, pp. 272-286.

Keiningham, T. L., Rust, R. T., Lariviere, B., Aksoy, L. and Williams, L. (2018), "A roadmap for driving customer word-of-mouth", Journal of Service Management, Vol. 29 No. 1, pp. 2-38.

King, R. A., Racherla, P. and Bush, V. D. (2014), "What We Know and Don't Know About Online Wordof-Mouth: A Review and Synthesis of the Literature", Journal of Interactive Marketing, Vol. 28 No. 3, pp. 167-183.

Kumar, V., Aksoy, L., Donkers, B., Venkatesan, R., Wiesel, T. and Tillmanns, S. (2010), "Undervalued or overvalued customers: Capturing total customer engagement value", Journal of Service Research, Vol. 13 No. 3, pp. 297-310.

Kunz, W., Aksoy, L., Bart, Y., Heinonen, K., Kabadayi, S., Ordenes, F. V., Sigala, M., Diaz, D. and Theodoulidis, B. (2017), "Customer engagement in a Big Data world", Journal of Services Marketing, Vol. 31 No. 2, pp. 161-171.

Lee, J., Park, D. and Han, I. (2008), "The effect of negative online consumer reviews on product attitude: An information processing view", Electronic Commerce Research and Applications, Vol. 7 No. 3, pp. 341-352.

Lee, M., Jeong, M. and Lee, J. (2017), "Roles of negative emotions in customers' perceived helpfulness of hotel reviews on a user-generated review website", International Journal of Contemporary Hospitality Management, Vol. 29 No. 2, pp. 762-783. 
Lee, M., Rodgers, S. and Kim, M. (2009), "Effects of Valence and Extremity of eWOM on Attitude toward the Brand and Website", Journal of Current Issues \& Research in Advertising, Vol. 31 No. 2, pp. 1-11.

Lee, Y. and Song, S. (2010), "An empirical investigation of electronic word-of-mouth: informational motive and corporate response strategy", Computers in Human Behavior, Vol. 26 No. 5, pp. 1073-1080.

Lemon, K. and Verhoef, P. (2016), "Understanding Customer Experience Throughout the Customer Journey", Journal of Marketing, Vol. 80 No. 6, pp. 69-96.

Liu, Z. and Park, S. (2015), "What Makes a Useful Online Review? Implication for Travel Product Websites", Tourism Management, Vol. 47 No. 1, pp. 140-151.

Maio, G., Haddock, G. and Verplanken, B. (2018), The psychology of attitudes and attitude change, Sage Publications Limited, London.

Mauri, A. and Minazzi, R. (2013), "Web reviews influence on expectations and purchasing intentions of hotel potential customers", International Journal of Hospitality Management, Vol. 34 No. 1, pp. 99-107.

MSI (2016), "Marketing Science Institute: 2016-2018 Research Priorities. Available at: http://www.msi.org/research/2016-2018-research-priorities/".

Mudambi, S. and Schuff, D. (2010), "What Makes a Helpful Online Review? A Study of Customer Reviews on

Amazon.com", MIS Quarterly, Vol. 34 No. 1, pp. 185-200.

Osuna Ramírez, S. A., Veloutsou, C. and Morgan-Thomas, A. (2019), "I hate what you love: brand polarization and negativity towards brands as an opportunity for brand management", Journal of Product \& Brand Management.

Park, C. and Lee, T. (2009), "Information direction, website reputation and eWOM effect: a moderating role of product type", Journal of Business Research, Vol. 62 No. 1, pp. 61-67.

Park, J., Robertson, R. and Wu, C.-L. (2004), "The effect of airline service quality on passengers' behavioural intentions: a Korean case study", Journal of Air Transport Management, Vol. 10 No. 6, pp. 435-439.

Perdue, C. and Summers, O. (1986), "Checking the Success of Manipulations in Marketing Experiments", Journal of Marketing Research, Vol. 23 No. 4, pp. 317-326.

Phillips, P., Barnes, S., Zigan, K. and Schegg, R. (2017), "Understanding the Impact of Online Reviews on Hotel Performance", Journal of Travel Research, Vol. 56 No. 2, pp. 235-249.

Putrevu, S. and Lord, K. (1994), "Comparative and Non-comparative Advertising : Attitudinal Effects under Cognitive and Affective Involvement Conditions", Journal of Advertising, Vol. 23 No. 2, pp. 77-90.

Qiu, L., Pang, J. and Lim, K. (2012), "Effects of conflicting aggregated rating on eWOM review credibility and diagnosticity: The moderating role of review valence", Decision Support Systems, Vol. 54 No. 1, pp. 631-643.

Reichelt, J., Sievert, J. and Jacob, F. (2014), "How Credibility Affects eWOM Reading: The Influences of Expertise, Trustworthiness, and Similarity on Utilitarian and Social Functions", Journal of Marketing Communications, Vol. 20 No. 1, pp. 65-81.

Reinstein, D. and Snyder, C. (2005), "The influence of expert reviews on consumer demand for experience goods: a case study of movie critics", The Journal of Industry Economics, Vol. 53 No. 1, pp. 27-51.

Rozin, P. and Royzman, E. (2001), "Negativity bias, negativity dominance, and contagion. ", Personal Social Psychology Review, Vol. 5 No. 4, pp. 269-320.

Sawhney, M. and Eliashberg, J. (1996), "A parsimonious model for forecasting gross box office revenues of motion pictures'", Marketing Science, Vol. 15 No. 2, pp. 113-131.

Schaefers, T. and Schamari, J. (2016), "Service Recovery via Social Media", Journal of Service Research, Vol. 19 No. 2, pp. 192-208. 
Schultz, W., Khazian, A. and Zaleski, A. (2008), "Using normative social influence to promote conservation among hotel guests", Social Influence, Vol. 3 No. 1, pp. 4-23.

Sen, S. and Lerman, D. (2007), "Why are you telling me this? An examination into negative consumer reviews on the Web", Journal of Interactive Marketing, Vol. 21 No. 4, pp. 76-94.

Smith, A. and Bolton, R. (1998), "An Experimental Investigation of Customer Reactions to Service Failure and Recovery Encounters: Paradox or Peril?", Journal of Service Research, Vol. 1 No. 1, pp. 65-81.

Sparks, B. and Bradley, G. (2014), "A "triple A" typology of responding to negative consumergenerated online reviews.", Journal of Hospitality \& Tourism Research., Vol. 41 No. 6, pp. 719-745.

Sparks, B. and Browning, V. (2011), "The impact of online reviews on hotel booking intentions and perception of trust", Tourism Management, Vol. 32 No. 6, pp. 1310-1323.

Sparks, B., So, K. and Bradley, G. (2016), "Responding to negative online reviews: The effects of hotel responses on customer inferences of trust and concern", Tourism Management, Vol. 53, pp. 74-85.

Triandis, H. (1971), Attitude and Attitude Change, John Wiley \& Sons, Inc., Canada.

Van Doorn, J., Lemon, K., Mittal, V., Nass, S., Pick, D., Pirner, P. and Verhoef, P. (2010), "Customer engagement behavior: Theoretical foundations and research directions", Journal of Service Research, Vol. 13 No. 3, pp. 253-266.

Van Noort, G. and Willemsen, L. (2012), "Online damage control: The effects of proactive versus reactive webcare interventions in consumer-generated and brand-generated platforms", Journal of Interactive Marketing, Vol. 26 No. 3, pp. 131-140.

Veloutsou, C. and Mafe, C. R. (2020), "Brands as relationship builders in the virtual world: A bibliometric analysis.", Electronic Commerce Research and Applications, Vol. 39 No. 1, p. 100901.

Verhoef, P., Reinartz, W. and Krafft, M. (2010), "Customer engagement as a new perspective in customer management", Journal of Service Research, Vol. 13 No. 3, pp. 247-252.

Verleye, K., Gemmel, P. and Rangarajan, D. (2014), "Managing engagement behaviors in a network of customers and stakeholders: Evidence from the nursing home sector", Journal of Service Research, Vol. 17 No. 1, pp. 68-84.

Vermeulen, I. E. and Seegers, D. (2009), "Tried and tested: The impact of online hotel reviews on consumer consideration", Tourism Management, Vol. 30 No. 1, pp. 123-127.

Wei, W., Miao, L. and Huang, Z. (2013), "Customer engagement behaviors and hotel responses", International Journal of Hospitality Management, Vol. 33 No. 1, pp. 316-330.

Weinberger, C. and Dillon, R. (1980), "The Effects of Unfavorable Product Information", in Olson, J. (Ed.) Advances in Consumer Research, Association for Consumer Research, Ann Arbor, MI, pp. 528-532.

Wilson, A. E., Giebelhausen, M. and Brady, M. (2017), "Negative word of mouth can be a positive for consumers connected to the brand", Journal of the Academy of Marketing Science, Vol. 45 No. 4, pp. 534-547.

Wirtz, J., Aksoy, L., den Ambtman, A., Bloemer, J., Horváth, C., Ramaseshan, B., van de Klundert, J., Gurhan Canli, Z. and Kandampully, J. (2013), "Managing brands and customer engagement in online brand communities", Journal of Service Management, Vol. 24 No. 3, pp. 223-244.

Wu, L., Mattila, A., Wang, C.-Y. and Hanks, L. (2016), "The impact of power on service customers' willingness to post online reviews", Journal of Service Research, Vol. 19 No. 2, pp. 224-238.

Wünderlich, N., Wangenheim, F. and Bitner, M. (2013), "High Tech and High Touch", Journal of Service Research, Vol. 16 No. 1, pp. 3-20.

Xie, K. L., Zhang, Z., Zhang, Z., Singh, A. and Lee, S. K. (2016), "Effects of managerial response on consumer eWOM and hotel performance", International Journal of Contemporary Hospitality Management, Vol. 28 No. 9, pp. 2013-2034. 
Ye, Q., Law, R. and Gu, B. (2009), "The Impact of Online User Reviews on Hotel Room Sales", International Journal of Hospitality Management, Vol. 28 No. 1, pp. 180-182.

Zhang, J. Q., Craciun, G. and Shin, D. (2010), "When does electronic word-of-mouth matter? A study of consumer product reviews", Journal of Business Research, Vol. 63 No. 12, pp. 1336-1341.

Zhang, L., Wu, L. and Mattila, A. (2016), "Online Reviews: The Role of Information Load and Peripheral Factors.", Journal of Travel Research, Vol. 55 No. 3, pp. 299-310.

Zimbardo, P. and Leippe, M. (1991), The psychology of attitude change and social influence, McgrawHill Book Company, England. 


\section{Appendix A}

(The stimulant material shown to participants was developed similar in appearance to a TripAdvisor page).

\section{Examples of Scenarios of Study 1}

\section{Indirect NVIB}

You are planning a vacation and while checking Hotels at the planned destination on TripAdvisor, you came across this review

\section{"A truly horrible place"}

This hotel is really, really bad. Unfortunately, the facilities haven't been updated. Peeling paint, noisy...food was awful... None of the staff were able to do anything without the manager's approval who conveniently were never available...1 electrical socket per room, the staff were horrible....A truly horrible place.

\section{Direct NVIB}

\section{“Don't Stay Here!!"}

This hotel is really, really bad. Unfortunately, the facilities haven't been updated. Peeling paint, noisy...food was awful... None of the staff were able to do anything without the manager's approval who conveniently were never available...1 electrical socket per room, the staff were horrible. Don't stay here!

\section{Examples of Scenarios of Study 2}

\section{Direct NVIB / High Aggregate Rating}

You are spending your vacation in another country and planning to have some dinner, while checking TripAdvisor, you came across this review posted to a restaurant with high aggregate rating

\section{"Don't Go There!!"}

We seated ourselves and had to sit at a dirty table while waiting around 10 minutes to simply get a menu and then waited a further 10-15 min for service. When we finally got out order, everthing was wrong. On top of that they tried to charge us for things we did not order. Overall terrible service and the food was horrible. Don't go there!

\section{Indirect NVIB/Low Aggregate Rating}

You are spending your vacation in another country and planning to have some dinner, while checking TripAdvisor, you came across this review posted to a restaurant with low aggregate rating

\section{"Disgraceful"}

We seated ourselves and had to sit at a dirty table while waiting around 10 minutes to simply get a menu and then waited a further 10-15 min for service. When we finally got out order, everthing was wrong. On top of that they tried to charge us for things we did not order. Overall terrible service and the food was horrible. 


\section{Examples of Scenarios of Study 3 \\ Indirect NVIB/ Equal Volume of Positive Reviews}

You are planning a vacation and while checking Hotels at the planned destination on TripAdvisor, you came across these reviews

\section{"A truly horrible place"}

This hotel is really, really bad. Unfortunately, the facilities haven't been updated. Peeling paint, noisy...food was awful... None of the staff were able to do anything without the manager's approval who conveniently were never available...1 electrical socket per room, the staff were horrible....A truly horrible place.

\section{"Good value"}

Had one night stay here and we thought it was good value!! Short walk to tube station. Continental breakfast with a variety of options. Clean room and excellent shower. The best is that it is close to everything and good for the price we paid.

\section{Direct NVIB/High Volume of Positive Reviews}

\section{“Don't Stay Here!!”}

This hotel is really, really bad. Unfortunately, the facilities haven't been updated. Peeling paint, noisy...food was awful... None of the staff were able to do anything without the manager's approval who conveniently were never available...1 electrical socket per room, the staff were horrible. Don't stay here!

\section{"Good value"}

Had one night stay here and we thought it was good value!! Short walk to tube station. Continental breakfast with a variety of options. Clean room and excellent shower. The best is that it is close to everything and good for the price we paid.

\section{"Nice break"}

It was a nice three nights staying. Clean, small but comfortable room. Kind receptionist, great location near the station and buses and good price. The breakfast was not so rich but overall it is good hotel for a short break.

\section{“Great location”}

A great location close to everything with variety of transportation links that makes it all easy to go anywhere. The hotel has a charm about it. Continental breakfast more than enough. A budget hotel but perfect for a few days sightseeing. Would book again. 


\section{Examples of Scenarios of Study 4}

Direct NVIB/Managerial Response

You are spending your vacation in another country and planning to have some dinner, while checking TripAdvisor, you came across this review.

\section{“Don't Go There!!"}

We seated ourselves and had to sit at a dirty table while waiting around 10 minutes to simply get a menu and then waited a further 10-15 min for service. When we finally got out order, everthing was wrong. On top of that they tried to charge us for things we did not order. Overall terrible service and the food was horrible. Don't go there!

\section{Response from the manager at the restaurant}

Good day...,

Thank you for taking the time to leave feedback from your visit to the restaurant. I am very sorry to read that your visit was not up to our usual standards and for that I completely apologize. I will ensure that your comments will not go unintended and be passed on to the relevant head of department. We really hop that this does not deter you from returning in the future, however, if you would like to discuss anything in any further detail, please don't hesitate to contact us.

Kind regards

\section{Indirect NVIB/ No Response}

\section{"Disgraceful"}

We seated ourselves and had to sit at a dirty table while waiting around 10 minutes to simply get a menu and then waited a further 10-15 min for service. When we finally got out order, everthing was wrong. On top of that they tried to charge us for things we did not order. Overall terrible service and the food was horrible. 


\section{Appendix B}

\begin{tabular}{|c|c|c|c|c|c|c|c|c|}
\hline \multirow{2}{*}{$\begin{array}{l}\text { Constructs and Items } \\
\text { Attitude (Bansal and Taylor, 1999, Cronin and Taylor, 1992, Putrevu and Lord, 1994) }\end{array}$} & \multicolumn{8}{|c|}{$\begin{array}{c}\text { Factors Loading1 \& } \\
\text { a/CR }\end{array}$} \\
\hline & \multicolumn{2}{|c|}{ Exp.1 } & \multicolumn{2}{|c|}{ Exp.2 } & \multicolumn{2}{|c|}{ Exp.3 } & \multicolumn{2}{|c|}{ Exp. 4} \\
\hline $\begin{array}{l}\text { Attitude (Bansal and Taylor, 1999, Cronin and Taylor, 1992, Putrevu and Lord, 1994) } \\
\text { My overall feeling about this hotel can be best described as (Very Unfavorable /Very favorable) } \\
\text { I think this hotel is (Very Poor / Excellent) } \\
\text { The decision to book this hotel is considered a good one (Strongly Disagree / Strongly Agree) }\end{array}$ & $\begin{array}{l}.95 \\
.92 \\
.93\end{array}$ & $\begin{array}{l}.88 / \\
.90\end{array}$ & $\begin{array}{l}.90 \\
.95 \\
.99\end{array}$ & $\begin{array}{l}.97 / \\
.92\end{array}$ & $\begin{array}{l}.98 \\
.97 \\
.99\end{array}$ & $\begin{array}{l}.99 / \\
.93\end{array}$ & $\begin{array}{l}.90 \\
.92 \\
.93\end{array}$ & $\begin{array}{l}.93 / \\
.90\end{array}$ \\
\hline $\begin{array}{l}\text { Behavioral Intentions (Gelbrich, 2010, Park et al., 2004) } \\
\text { Would you consider booking this hotel? } \\
\text { Would you recommend it to other people? } \\
\text { I would tell other people good things about the hotel }\end{array}$ & $\begin{array}{l}.90 \\
.85 \\
.86\end{array}$ & $\begin{array}{l}.80 / \\
.92\end{array}$ & $\begin{array}{l}.98 \\
.97 \\
.95\end{array}$ & $\begin{array}{l}.96 / \\
.93\end{array}$ & $\begin{array}{l}.95 \\
.98 \\
.99\end{array}$ & $\begin{array}{l}.98 / \\
.90\end{array}$ & $\begin{array}{l}.91 \\
.88 \\
.90\end{array}$ & $\begin{array}{l}.90 / \\
.96\end{array}$ \\
\hline \multicolumn{9}{|l|}{ Confounding Variables ${ }^{\mathrm{b}}$} \\
\hline $\begin{array}{l}\text { Attitude towards Checking Online Reviews (Donthu and Gilliland, 1996, Qiu et al., 2012) } \\
\text { Online reviews are helpful for my purchase decision making } \\
\text { If I do not read online reviews prior to purchase, I will feel worried about my decision } \\
\text { I want to be sure about my purchase decisions }\end{array}$ & $\begin{array}{l}.83 \\
.85 \\
.87\end{array}$ & $\begin{array}{l}.82 / \\
.91\end{array}$ & $\begin{array}{l}.98 \\
.99 \\
.90\end{array}$ & $\begin{array}{l}.96 \\
.89\end{array}$ & $\begin{array}{l}.85 \\
.93 \\
.89\end{array}$ & $\begin{array}{l}.87 / 1 \\
.98\end{array}$ & $\begin{array}{l}.88 \\
.90 \\
.91\end{array}$ & $\begin{array}{l}.88 / \\
.98\end{array}$ \\
\hline $\begin{array}{l}\text { Perceived TripAdvisor Credibility (Qiu et al., 2012) } \\
\text { In general, I think TripAdvisor is trustworthy } \\
\text { In general, I think TripAdvisor is reliable } \\
\text { In general, I think TripAdvisor is credible }\end{array}$ & $\begin{array}{l}.91 \\
.96 \\
.92\end{array}$ & $\begin{array}{l}.94 / \\
.89\end{array}$ & $\begin{array}{l}.95 \\
.96 \\
.93\end{array}$ & $\begin{array}{l}.98 / \\
.90\end{array}$ & $\begin{array}{l}.98 \\
.99 \\
.97\end{array}$ & $\begin{array}{l}.98 / \\
.95\end{array}$ & $\begin{array}{l}.88 \\
.83 \\
91\end{array}$ & $\begin{array}{l}.90 / \\
.85\end{array}$ \\
\hline $\begin{array}{l}\text { Attribution of Blame (Gelbrich, 2010) } \\
\text { The service provider is responsible for the problem } \\
\text { The reason for the problem is something the service provider had control over } \\
\text { The service provider could have taken action to prevent the problem but has not }\end{array}$ & & & & & & & $\begin{array}{l}.90 \\
.95 \\
.92\end{array}$ & $\begin{array}{l}.95 / \\
.90\end{array}$ \\
\hline
\end{tabular}

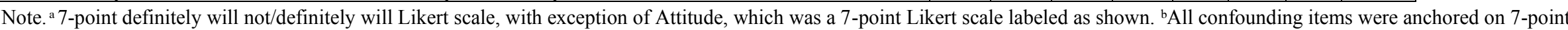
strongly disagree/strongly agree Likert-type scale. ${ }^{1}$ Standardized Loadings: all loadings were significant at $\mathrm{p}<.001$.

\begin{tabular}{|c|c|c|c|c|c|c|c|c|c|c|c|c|c|c|c|c|c|}
\hline & \multicolumn{4}{|c|}{ Study 1} & \multicolumn{4}{|c|}{ Study 2} & \multicolumn{4}{|c|}{ Study 3} & \multicolumn{5}{|c|}{ Study 4} \\
\hline & \multirow[t]{2}{*}{ AT } & \multirow[t]{2}{*}{$\mathbf{B E}$} & \multirow{2}{*}{$\begin{array}{c}\text { Conf } \\
1\end{array}$} & \multirow{2}{*}{$\begin{array}{c}\text { Conf } \\
2\end{array}$} & \multirow[t]{2}{*}{$\mathbf{A T}$} & \multirow[t]{2}{*}{$\mathbf{B E}$} & \multicolumn{2}{|c|}{ Conf Conf } & \multirow[t]{2}{*}{$\mathbf{A T}$} & \multirow[t]{2}{*}{$\mathbf{B E}$} & \multicolumn{2}{|c|}{ Conf Conf } & \multirow[t]{2}{*}{ AT } & \multirow[t]{2}{*}{$\mathbf{B E}$} & \multicolumn{3}{|c|}{ Conf $\mid$ Conf Conf } \\
\hline & & & & & & & 1 & 2 & & & 1 & 2 & & & 1 & 2 & 3 \\
\hline Attitudes (AT) & .89 & & & & .88 & & & & .82 & & & & .81 & & & & \\
\hline Behavioral Intentions (BE) & .402 & .80 & & & .482 & .85 & & & .444 & .84 & & & .468 & .79 & & & \\
\hline Attitudes towards checking online reviews (Conf1) & .201 & .292 & .87 & & .101 & .194 & .87 & & .258 & .294 & .75 & & .200 & .294 & .83 & & \\
\hline Perceived Credibility of TripAdvisor (Conf2) & .206 & .237 & .121 & .84 & .236 & .290 & .243 & .84 & .288 & .230 & .443 & .77 & .188 & .330 & .413 & .77 & \\
\hline Attribution of Blame (Conf3) & & & & & & & & & & & & & .305 & .285 & .140 & .200 & .85 \\
\hline
\end{tabular}

Note: Italicized diagonal elements are the square root of AVE for each construct. Off-diagonal elements are the correlations between constructs 